\title{
Pedagogical Perspectives on Teaching Materials of Translation in English Language Teaching
}

\author{
Masitowarni Siregar \\ Universitas Negeri Medan, Indonesia \\ Email Correspondence: masitowarnisiregar@unimed.ac.id
}

\begin{abstract}
Background:
Abstract

Instructional materials for vocational schools encounter distinguishing features; it manages to take on the English for Special Purposes (ESP). This research was carried out to seek the data of teaching materials for Vocational Schools in Indonesia. It used a survey procedure to gather the English teachers' perspectives. It stressed the Translation skill.
\end{abstract}

Methodology:

A survey design was utilized to gather the data. With a Purposive Sampling Technique, it involved 30 vocational English teachers in Sumatera Utara Province. A set of questionnaires was administered to gain the perspective of English teachers about the translation materials and teaching process in some Vocational Schools. It used a Likert Scale to determine the values responses of samples.

\section{Findings:}

Data gained indicated that $52.45 \%$ of respondents agreed with the teaching material, and $43.10 \%$ strongly agreed with those. Only $4.45 \%$ of respondents strongly disagreed with those topics. Data analysis showed that the 58 elements in the Subject of Translation in ELT had covered the teaching materials in Vocational school.

\section{Conclusion:}

It concluded that translation is a fundamental element of the instructional system in English as a foreign language in Indonesia. Based on this notion, the Vocational English teachers in Indonesia should be trained to consider the appropriate ways of translating by knowing the theories and practice of translating within English teaching material.

Keywords: pedagogical translation; English teacher; ELT; vocational school

\begin{tabular}{|c|c|c|}
\hline DOI & : & http//dx.doi.org/10.24903/sj.v6i1.684 \\
\hline Received & : & February 2021 \\
\hline Accepted & $:$ & March 2021 \\
\hline Published & : & April 2021 \\
\hline Copyright Notice & : & $\begin{array}{l}\text { Authors retain copyright and grant the journal right of first publication with the } \\
\text { work simultaneously licensed under a Creative Commons Attribution } 4.0 \\
\text { International License that allows others to share the work with an acknowledgement of } \\
\text { the work's authorship and initial publication in this journal. } \\
\text { (c) (i) () }\end{array}$ \\
\hline
\end{tabular}




\section{INTRODUCTION}

Intensive research on the English lesson as a compulsory subject in Vocational Schools is needed to conduct for seeking the data of pedagogical perspectives, teaching materials, and the problems of language learning at the Senior Vocational School level. This study was carried out to seek the pedagogical perspective of English teachers in vocational Schools based on the survey research. When two communities of speakers with different languages and do not comprehend each other would like to communicate both in spoken and written mode, they may utilize translation (Chistova, 2019; Yenkimaleki \& van Heuven, 2018). In many nations, the establishment of the utilization of translation in the teaching of foreign language setting in higher education designed at preparing the candidate language teachers for their possible prototypical profession, as well as directing the candidate foreign language teachers to be able to use translation as a method of foreign language teaching efficiently (M. A. Thawabteh, 2009). A pedagogical study of discussion interpreting emphasizes the urgent of the interpreter need to involving and not involving interlocutors; this idea is also true with the foreign langue learners' consideration in the instructional process (Arbain, 2020; Havnen, 2021; Maulana et al., 2020).

More than 30 years ago, the consideration of the pedagogical paradigm, that originated from the Direct Method of the instructional process, further repressed the role of Translation in Language Teaching (TILT) (Kelly \& Bruen, 2015). Several pedagogical translations have a big impact on the teaching materials for English as a foreign language (David et al., 2019; Hernández-Ching, 2019; L Pintado Gutiérrez, 2021). Furthermore, the unclear function of translation role in the Vocational Schools in Indonesia, this research was carried out to find the teachers' perspective and its implication to translation pedagogy and teaching materials.

Many studies have revealed that translation pedagogy now has to shift from old ideas and adopt the cultural and linguistic knowledge in real-time communication' (Blum \& Hofeneder, 2020). "Theoretical assumptions can only be arrived at through research", which, can contribute to the development of new pedagogical tools (M. Thawabteh, 2017). New models make the unfolding research and pedagogical translations (Bowker, 2008). Adaptation to the present use of tools for teaching English with the future developments of the research agenda. Furthermore, the insignificant design has made the translation pedagogy in reverse not moving forward to new models (Heywood \& Harding, 2021). New models of teaching practices for translation shift from the know-how and non-contextual texts perspective which has made the translation class a word-to-word caption. Thus, New models take the involved 
elements in pedagogical translation; a student center orientation, the use of IT, and cultural exchanges (Blum \& Hofeneder, 2020). Endeavors with a more elaborative objective coming from software manufacturers, the translation industry and academia have tried to assess or analyze available translation workstations (Alonso Jiménez \& De-la-Cova, 2014).

Based on the ideas of creating the pedagogical translation with a more deliberate teaching model, this study applied an integrated perspective. Content and language integrated learning refer to a wide variety of pedagogical perspectives entailing double center on both lingual and substance constituents (Czura, 2020). Some experts put forward the immediate direct use in constructing foreign languages (Carreira, 2018; Siregar, 2019; Thi \& Pham, 2017). Some experts in quite different contexts investigating the issue. Research on existing problems caused by teacher behavior changes can trigger further research by the context of the problem. Foreign language teachers should realize the importance of students' utilization of translation in the process of language teaching and learning in primary, secondary and higher educational levels and in the same time help the leaners to improve their English competency (Ducar \& Schocket, 2018).

Translation in English class as a foreign language often takes attention and time allocation in Indonesia. Such as translation often makes the English class more focused on helping learners to understand the reading texts. Moreover, the functions of translation in the teaching and learning process of a new language have gained more considerable evaluation within the last decades (Gutiérrez, 2018). The translation is regarded as a tool to communicate among different cultures involving experts on this more getting attention notion. Recently, more discussion has been given to the academic organization related to the progress of translation (Kafi et al., 2018). Present discussion among the process of acquiring a second and foreign language, language instruction as well translation disciplines seem not to be very well established (Colina, 2002). Because the translation is essentially a multifaceted study, the vision of pedagogical translation is regarded to be a notion from other disciplines to gain its construct in terms of theory and pragmatics. The discussion of many notions of translation within foreign and second language teaching and learning has become a new paradigm within the context of foreign and second language teaching and learning issues among foreign language educators with the sense of new adaptation in applied linguistics studies (Bell \& Lygo-Baker, 2019; Bi, 2020; Bruen \& Kelly, 2017).

From the international perspective, people all over the world are learning English at school and other formal institutions to have a better job and to function in the academic context. English becomes a school subject and is required to own a bargain in the job position. It occurs 
as high unemployment exists and English mastery is much appreciated in the workplace, business, and tourism. Not surprisingly, the present notions and ideas on the teaching and learning of foreign language teaching especially English are gaining more attention from language instructors, researchers, policymakers. Some foreign language teachers face problems with selecting the material, developing teaching and learning movements. (Raynesa Noor Emiliasari, 2019). With the more attention and realization given to the need for English in international communication, foreign language instructors face difficult work to prepare and develop teaching material that suits international demand (Galloway \& Rose, 2018). Foreign language teachers and foreign language researchers should build more understanding and comprehension of the material needed for international content and contexts to be used in the classrooms. (Stephenson \& Hall, 2020). Foreign language educators and researchers are trying to build more educational frameworks for this context of international demand (Smith, 2021).

In Indonesia, the utilization of translation motions in the English teaching and learning process is real. This fact is supported by the Professional English Teacher Program's facts indicated that most of the teachers use translation during the process of teaching and learning. But to some extent, their use of translation is sometimes misleading. Some vocational English teachers who have joined the Professional English Teacher Program have been found making an incorrect use of translation during their practice teaching; for example, when they are going to call the roll, they say, "Let's take absent"; it is from the translation of "Sekarang Ibu mau ambil absen kalian". Another teacher translated "Faithfully yours" in the closing section of a formal letter into "Diriku yang setia". The previous examples make the translation skill of English teachers for Indonesia's Vocational Schools need to redesign.

Students' utilization of English in the context of foreign language teaching in Indonesia is quite imposing for the government to decide English to the national assessment. Thus, Rasman (2018) reported that the English instructor in Indonesia is facing problems in speaking in English with the English learners in their classroom. A description of English class shows that they are only giving a lengthy explanation on grammar with very limited real English conversation, Teaching and learning process with low quality, correct the students' mistakes and make misapprehension (Nasir et al., 2019).

In recent years, partnerships in education were established by having collaboration between schools and universities on participated teaching and action research collaboration. The outcome of the collaborative research is in form of suggestions to the school, and the universities to utilize more considerable views on the practice of English language teaching at 
school and universities (Eickhoff \& De Costa, 2018). The idea of translanguaging which acknowledge the existence of students various background: their culture, their language might help motivate the students to the foreign language they are studying; letting the students speak sometimes in their mother tongue and then speak that expression in English will add on their spirit in the teaching and learning process. This motivates the students to correlate what they already have and what they would learn. This in turn is expected to build the number of vocabularies they are learning to function well in the target language being learned (Illman \& Pietilä, 2018).

Based on this situation, in the English Educational Study Program Curriculum (EESP) curriculum, the need for a subject focusing on the competency to train prospective teachers to translate English teaching materials that they are going to translate is urgently needed. Therefore, this study sought to determine vocational English teachers' perspectives on the teaching material for The Subject Pedagogical Translation in ELT.

For teaching translation for Pedagogical Purpose in the classroom, students in English Educational Study Program in North Sumatra who are prospective English teachers should have English and Indonesian translation skills and commands. English teachers need to apply linguistic competence because translation is a teacher's foundation in teaching the language of a language to study a text and interpret a message in a language that is translated into a foreign language.

\section{METHODOLOGY}

A Survey Research was applied to seek the Perspective of English teachers on translation skills, teaching materials and pedagogical aspects of Vocational Schools. This study by using a survey is regarded as gathering data from individuals or groups by which answers to the questions are gained. This design permits various methods of involving sample population and sample, gain data, and use a number of data collection techniques. Survey design may utilize several quantitative study ground plans (e.g., utilizing questionnaires with number scale elements), qualitative study ground plan (e.g., utilzing open-ended questionnaires), or the two ground plans (i.e., combined techniques) (Ponto, 2015). The three basic goals of survey research are description, ex- planation, and exploration (Brommage, 2006).

It took 30 English Teachers of vocational Schools in North Sumatra with the Purposive Sampling Procedure. It means the samples have experience in practice pedagogical translation in vocational schools for many years and have the professional position to fill the instruments. 
In vocational schools, during collecting the data in the field, the researcher had the teachers give the responses to the administered questionnaires. The questionnaire that was used to collect the data had the 58 elements that were responded to by the 30 samples. The questionnaire has nine areas, namely a) translation viewpoint b) translation grounded on pedagogical purpose viewpoint, c) teaching process of translation purpose perspective, d) community relation, e) instructional relation, f) Apparatus and origin of instruction, g) publication and dispersion, h) Classification of knowledge of translation depend on English teaching purpose, and i) Themes of Translation depend on English teaching purpose, in 58 queries. The data analysis technique used was the Likert Scale from 1 (strongly disagree) to 5 (strongly agree).

\section{FINDINGS}

Out of the three (3) facets in the questionnaire of the requirement of level analysis, there are 59 elements which had been responded by the 30 informants of Vocational English Teachers' Perspective on Teaching Material for Pedagogical Purpose in the Translation in ELT Subject. Data obtained put into a Likert Scale, the results are made from diagram 1;

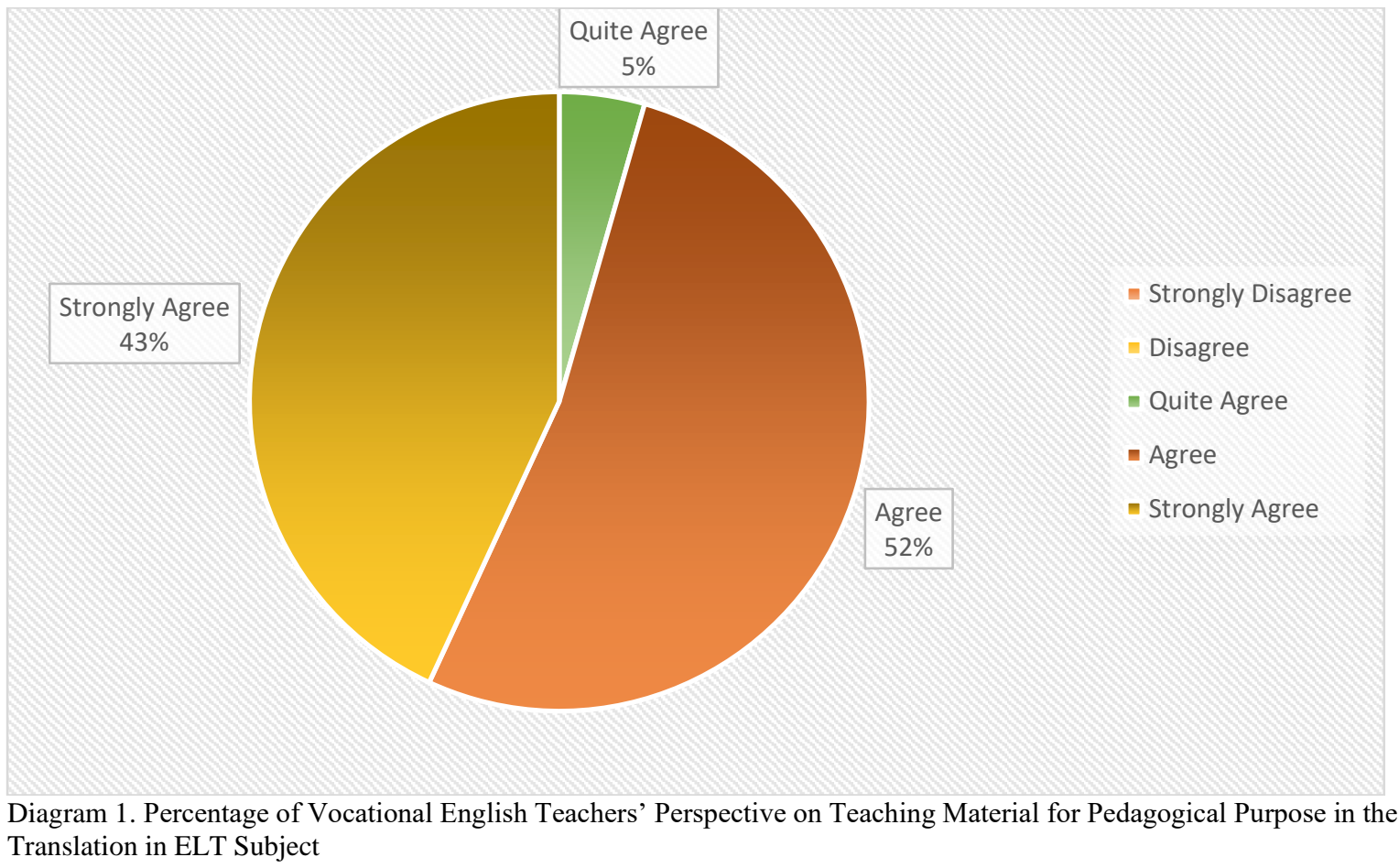

Diagram 1 shows the percentage of Vocational English Teachers' Perspective on Teaching Material for Pedagogical Purpose in the Translation in ELT Subject prospective teachers of English from the vocational English teachers' points of view of the 58 elements in 12 areas and 3 facets of the materials, from 30 respondents, it indicated that $52.45 \%$ of the 58 elements are important for the learners or prospective English teachers. Furthermore, $43.1 \%$ of 
the 58 elements are indispensable and only $4.45 \%$ of the 58 elements quite agree. Next, none of the 58 elements given is unnecessary from the perspective of the respondents. This means student's necessities in the perspective of the respondents are following what is tied in the analysis of the demands of the translation teaching material depend on English Teaching on Purpose. Thus, the overall aspects contained in the questionnaire have to be put in the translation learning text to be planned and established for they are regarded important in the participants' point of view.

All of the respondents also are in the opinion that the translation materials to be learned at the translation in ELT Subject should incorporated topics base on Vocational School English. These vocational English teachers, realizing that 9 broad areas are compromising 35 sub-areas of vocational schools suggest that some materials represented English in vocational or English for Specific Purposes should be covered in the learning resources. These are very important because the nature of translating materials in general English is quite different from English for specific purposes, they suggest.

\section{DISCUSSION}

Referring to the data obtained which show $52.45 \%$ of respondents agreed with the current teaching materials of English lessons for vocational schools, and $43.10 \%$ strongly agreed with those. Only $4.45 \%$ of respondents strongly disagreed with those topics. Data analysis showed that the 58 elements in the Subject of Translation in ELT had covered the teaching materials in Vocational school. It means that only the teaching-learning procedures and techniques should be designed to a better one. In the survey, samples were asked about the role of the linguistic aspects in detail in the source language and target language. Respondents' ideas concerning the mastery of educational terms in the source language and target language. English teachers were asked about terminologies of Vocational Schools materials in the classroom in the source language and target language. Thus. questionnaires probed the samples thought about the cultural understanding of the source language and target language in general.

Respondents in data obtained have given the real condition of translation skill and teaching materials of Vocational Schools in North Sumatera Province. It showed that it indicated that $52.45 \%$ of the 58 elements are important for the learners or prospective English teachers. Thus teachers who strongly agreed with 58 elements are 43.1\%. Data analysis indicated that the "students need analysis" has been the main priority in selecting the teaching materials for the English Subject in Vocational Schools. Since the English Subject function in 
Vocational Schools as Adaptive Lesson; that is helping the students find the knowledge about techniques and Business Administration that written in English to help the students enlarge their vocational education, so translation practices should be emphasized. Thus, English is the additional text for students to deepen their understanding and comprehend reading materials about skills and technology improvements in vocational education. English instruction in the vocational program, especially in the secondary program, can be regarded as the English for Specific Purposes (usually addressed ESP) domain (Mahbub, 2018). English in Vocational Program falls into the category of English for Specific Purposes (ESP) with regarded as the perspective to foreign language instruction positioning to fulfill the demand of specific students (Muliyah \& Aminatun, 2020).

English as a medium to add the students' knowledge about technical and business materials. We know that the internet has created many advanced knowledge and skills in many parts of modern life. Information and Communication Technology provides some features that make human interaction and industry growth very fast. This phenomenon supports the English for Specific Purposes (ESP) materials for Vocational Schools need tremendous improvement.

English for Specific Purposes is considered to have exact features, that usually utilize and elements feature that is probably based on specific conditions. English for Specific Purposes is built is to fulfill special demand of students; English for Specific Purpose utilize the underpinning ground plan and motions of the subject they serve (Susilowati, 2008). English for Specific Purpose is central to the linguistics (structure, sentence, register) psychomotor, texts and genre suitable to this activity (Huang \& Foreign, 1998). English for Specific Purpose is a viewpoint to language instruction where all conclusions to the subject matter and strategies are considered on the students' motives for studying (Mayhew et al., 2020). Another significant strategy is to focus on students' activities to achieve vocabularies related to the setting of ESP they studying. (Cahill et al., 2009). Data obtained in this research has shown that teaching materials for the Subject of English in a Vocational school need a specific theme. Since Vocational Schools' nature is different from Senior High Schools, the teaching materials for English lessons in Vocational School should be suitable with the English for Specific Purposes (ESP). Respondents defended their opinion that the themes of translation depend upon English Teaching Purpose in Vocational Schools.

Respondents agreed that the English for Specific Purposes (ESP) materials cover digital machinery, energy, and business are electronic and computer integrated tools. Digital should be attached to the English Subject for Vocational Schools. Digital knowledge has been 
extended to many sectors, and digital technology opportunities will grow faster and faster. As a result, the students will compete with others to seek jobs requiring computer and digital technology competencies. English Subject which prepares students to study the computer and digital technology for Automotive, Machines and Business Management should be vital for Vocational Schools.

Respondents also think of the future of the English Subject as a medium to improve students' knowledge and skills, not only in English in general, but a tool to sharpen their technical understanding of students' dispensation. It implies that the English teachers in technical and business Vocational Schools should add extra materials from the internet and online journals, booklets, brochures and fliers that contain the new advanced technology information.

The vocational English teachers recommended that the Translation subject materials in the English Educational Study program are related to the nature of the vocational school that they are teaching. They also admit that the material should be packed within the curriculum approach, namely, the functional Approach. For these reasons, the materials are in the English Curriculum framework but integrated with English for vocational context.

Even though this research reached the Vocational Schools teaching-learning process for English subject, but it has three limitations: 1). it has a small sample, 2). it only made survey research without any treatments, and 3). the integrated English Curriculum was not applied in the study. For further study, it needs to consider the 3 weaknesses of this research.

\section{CONCLUSION}

Considering the results of the research, some conclusions are drawn. First, the English teachers who strongly agreed with 58 elements of translation skill and materials for Vocational Schools are $43.1 \%$. A translation syllabus is a fundamental part of the English instructional system in English as a foreign language in Indonesia.

Second, the appropriate ways of translating by knowing the theories and practice of translating within English teaching material are needed. Consequently, the English Educational Study Program curriculum, which produces these teachers, should provide these Subjects. The translation should provide the preparing condition to the candidate teachers to use translation to translate materials in vocational schools.

Some suggestions are offered based on the conclusion. First, the lecturer should consider selecting and designing material relevant to the material taught for prospective English teachers. Second, it is suggested that all the heads of the English educational study 
program integrate translation materials based on English for teaching purposes. Third, the next researchers can utilize the study's result to the standpoints for the next similar study. The possible next research issues are on the themes, techniques, assessment, and testing of translation materials based on English teaching purposes.

\section{REFERENCES}

Alonso Jiménez, E., \& De-la-Cova, E. (2014). Apuntes metodológicos para la aplicación de la socionarrativa a la evaluación de herramientas de traducción: «Érase una vez Google Translator Toolkit». Revista Tradumàtica: Traducció i Tecnologies de La Informació $i$ La Comunicació, 12, 508-523.

Arbain, A. (2020). Translating subtitles of becoming Jane Film: A pragmatic approach. Langkawi: Journal of The Association for Arabic and English, 6(1), 17-28. https://doi.org/DOI: http://dx.doi.org/10.31332/lkw.v6i1.1766

Bell, L., \& Lygo-Baker, S. (2019). Student-centred learning: a small-scale study of a peerlearning experience in undergraduate translation classes. Language Learning Journal, 47(3), 299-312. https://doi.org/10.1080/09571736.2016.1278030

$\mathrm{Bi}, \mathrm{W}$. (2020). Translation in German as a second foreign language teaching in China - a case study . Deutsch als Fremdsprache, 57(2), 102-111. https://www.scopus.com/inward/record.uri?eid=2-s2.085091856446\& partnerID=40\&md5=8e30f7dbe53824b3c508d2beec9b1059

Blum, H., \& Hofeneder, P. (2020). Specialized translators in the GDR. Translation and Interpreting Studies, 15(3), 333-353. https://doi.org/10.1075/tis.20077.hof

Bowker, L. (2008). Official language minority communities, machine translation, and translator education: Reflections on the status quo and considerations for the future. TTR: Traduction, Terminologie et Redaction, 21(2), 15-61. https://doi.org/10.7202/037491ar

Brommage, D. (2006). Survey Research. Journal of Renal Nutrition, 16(4), 348-350. https://doi.org/10.1053/j.jrn.2006.07.001

Bruen, J., \& Kelly, N. (2017). Using a shared L1 to reduce cognitive overload and anxiety levels in the L2 classroom. Language Learning Journal, 45(3), 368-381. https://doi.org/10.1080/09571736.2014.908405

Cahill, P., Du, J., Way, A., \& Carson-Berndsen, J. (2009). Using same-language machine translation to create alternative target sequences for text-to-speech synthesis. Proceedings of the Annual Conference of the International Speech Communication Association, INTERSPEECH, May 2014, 1307-1310.

Carreira, V. A. (2018). Pedagogical translation and mother tongue in the teaching and learning of english for science and technology. Hermeneus, 20, 37-56. https://doi.org/10.24197/her.20.2018.37-56

Chistova, E. V. (2019). Speech recognition technology in cognitive translation studies. Journal of Siberian Federal University - Humanities and Social Sciences, 12(1), 47-54. https://doi.org/10.17516/1997-1370-0229

Colina, S. (2002). Second language acquisition, language teaching and translation studies. Translator, 8(1), 1-24. https://doi.org/10.1080/13556509.2002.10799114

Czura, A. (2020). Translation is not Enough - the Need for Pedagogical Adaptation in CLIL Textbook Development. Porta Linguarum Revista Interuniversitaria de Didáctica de Las Lenguas Extranjeras, 35-46. https://doi.org/10.30827/digibug.53950

David, S. S., Pacheco, M. B., \& Jiménez, R. T. (2019). Designing Translingual Pedagogies: Exploring Pedagogical Translation through a Classroom Teaching Experiment. 
Cognition and Instruction, 37(2), 252-275.

https://doi.org/10.1080/07370008.2019.1580283

Ducar, C., \& Schocket, D. H. (2018). Machine translation and the L2 classroom: Pedagogical solutions for making peace with Google translate. Foreign Language Annals, 51(4), 779-795. https://doi.org/10.1111/flan.12366

Eickhoff, L., \& De Costa, P. I. (2018). Collaborative teaching reflection: Insights into a globalized partnership. ELT Journal, 72(2), 121-130. https://doi.org/10.1093/elt/ccx041

Galloway, N., \& Rose, H. (2018). Incorporating Global Englishes into the ELT classroom. ELT Journal, 72(1), 3-14. https://doi.org/10.1093/elt/ccx010

Havnen, R. (2021). Fight for focus: attention and agency in sight-translated interaction. Perspectives: Studies in Translation Theory and Practice, 0(0), 1-18. https://doi.org/10.1080/0907676X.2021.1892785

Hernández-Ching, R. C. (2019). The relevance of pedagogical translation for the development of bilingual education in Costa Rica . Revista Electronica Educare, 23(1), 1-16. https://doi.org/10.15359/ree.23-1.2

Heywood, E., \& Harding, S. A. (2021). 'If you've done a good job, it's as if you've never existed": Translators on translation in development projects in the Sahel. Translation Studies, 14(1), 18-35. https://doi.org/10.1080/14781700.2020.1749122

Huang, K., \& Foreign, A. (1998). An Investigation of Students 'Attitudes to the Utilization of the Communicative Translation Teaching ( CTT ) in College English Translation Classrooms. 2008.

Illman, V., \& Pietilä, P. (2018). Multilingualism as a resource in the foreign language classroom. ELT Journal, 72(3), 237-248. https://doi.org/10.1093/elt/ccx073

Kafi, M., Khoshsaligheh, M., \& Hashemi, M. R. (2018). Translation profession in Iran: current challenges and future prospects. Translator, 24(1), 89-103. https://doi.org/10.1080/13556509.2017.1297693

Kelly, N., \& Bruen, J. (2015). Translation as a pedagogical tool in the foreign language classroom: A qualitative study of attitudes and behaviours. Language Teaching Research, 19(2), 150-168. https://doi.org/10.1177/1362168814541720

Mahbub, M. A. (2018). ENGLISH TEACHING IN VOCATIONAL HIGH SCHOOL: A NEED ANALYSIS. Journal of English Education and Linguistic Studies, 5(2), 229258.

Maulana, A. Z., Nababan, M., \& Santosa, R. (2020). Evaluative Language Maintenance and Shift on Vice-Presidential Candidates Reportage: Translation Analysis of 'The Conversation'Political News. Script Journal: Journal of Linguistics and English Teaching, 5(2), 165-178. https://doi.org/https://doi.org/10.24903/sj.v5i2.562

Mayhew, S., Bicknell, K., Brust, C., McDowell, B., Monroe, W., \& Settles, B. (2020). Simultaneous Translation and Paraphrase for Language Education. Wngt, 232-243. https://doi.org/10.18653/v1/2020.ngt-1.28

Muliyah, P., \& Aminatun, D. (2020). Teaching English for Specific Purposes in Vocational High School : Teachers 'Beliefs and Practices. Journal of English Teaching, 6(2), 122133.

Nasir, C., Yusuf, Y. Q., \& Wardana, A. (2019). A qualitative study of teacher talk in an EFL classroom interaction in Aceh Tengah, Indonesia. Indonesian Journal of Applied Linguistics, 8(3), 525-535. https://doi.org/10.17509/ijal.v8i3.15251

Pintado Gutiérrez, L. (2021). Translation in language teaching, pedagogical translation, and code-Switching: restructuring the boundaries. Language Learning Journal, 49(2), 219 239. https://doi.org/10.1080/09571736.2018.1534260

Pintado Gutiérrez, Lucía. (2018). Translation in language teaching, pedagogical translation, and code-Switching: restructuring the boundaries. Language Learning Journal, O(0), 1- 
21. https://doi.org/10.1080/09571736.2018.1534260

Ponto, J. (2015). Understanding and Evaluating Survey Research. Journal of the Advanced Practitioner in Oncology, 6(2), 168-16871.

Rasman. (2018). To translanguage or not to translanguage? The multilingual practice in an indonesian EFL classroom. Indonesian Journal of Applied Linguistics, 7(3), 687-694. https://doi.org/10.17509/ijal.v7i3.9819

Raynesa Noor Emiliasari. (2019). Lesson Planning in EFL Classroom: A Case Study in Lesson Plan Preparation and Implementation. Wiralodra English Journal, 3(2), 367375. https://doi.org/10.31943/wej.v3i2.67

Siregar, M. (2019). Model of Translation Textbook for Teaching English as Foreign Language (TEFL) Pedagogical Purpose. SALTeL Journal (Southeast Asia Language Teaching and Learning), 2(2), 72-82. https://doi.org/10.35307/saltel.v2i2.34

Smith, R. (2021). A brief history of ELT Journal. ELT Journal, 75(1), 4-13. https://doi.org/10.1093/elt/ccaa065

Stephenson, M., \& Hall, G. (2020). Organizing talk in group speaking tests: learning from high-scoring students. ELT Journal, 75(December 2020), 42-54. https://doi.org/10.1093/elt/ccaa052

Susilowati, E. (2008). ESP AS AN APPROACH OF ENGLISH LANGUAGE TEACHING IN ITS Endang Susilowati. Jurnal Sosial Humaniora, 1(1).

Thawabteh, M. (2017). Subtitling on the Intersection of Theory and Practice: Pedagogical Research-Based Approach to Subtitler Training. Arab World English Journal For Translation and Literary Studies, 1(1), 32-47. https://doi.org/10.24093/awejtls/vol1no1.3

Thawabteh, M. A. (2009). Apropos translator training aggro: A case study of the Centre for Continuing Education. Methodology, July, 165-179.

Thi, C., \& Pham, K. (2017). Reading Comprehension and Translation Performance of English Linguistics Students of Hung Vuong University: A Correlational Study. International Journal of English Language \& Translation Study, 05(03), 79-85.

Yenkimaleki, M., \& van Heuven, V. J. (2018). The effect of teaching prosody awareness on interpreting performance: an experimental study of consecutive interpreting from English into Farsi. Perspectives: Studies in Translatology, 26(1), 84-99. https://doi.org/10.1080/0907676X.2017.1315824 